Расколы и секты в Приазовье и органы власти Российской империи: несостоявшийся компромисс в XIX веке

\author{
T. С. Оленич \\ Донской государственный технический университет, \\ Российская Федерация, 344000, Ростов-на-Дону, пл. Гагарина, 1
}

Для цитирования: Оленич Т. С. Расколы и секты в Приазовье и органы власти Российской империи: несостоявшийся компромисс в XIX веке // Вопросы теологии. 2020. T. 2, № 3. C. 480-489. http://doi.org/10.21638/spbu28.2020.307

В статье рассмотрены некоторые факторы роста и распространения, а также статистического учета сектантских организаций и старообрядческих общин на территории Приазовья в XIX в. Процессы распространения сектантских организаций в то время были весьма активными, так как они имели широкую социальную базу и динамично распространялись, несмотря на ограничения со стороны официального правительства, а деятельность Русской православной церкви по противодействию процессу распространения сектантских учений была ограничена действовавшими законами. Показано, что некоторые представители сектантства маскировалась под православных и компактно проживали в границах церковных приходов. Охарактеризованы сложившиеся политико-правовые условий распространения сект, а также особенности сложившейся в регионе системы религиозных взаимоотношений. Особенно активно процесс распространения сектантства проходил на территории Екатеринославской губернии, где действовали такие сектантские организации, как молокане, хлысты, скопцы и др. На основе архивных данных исследована численность таких сект, а также выявлено количество общин старообрядческого раскола. Проанализирована специфика сложившихся в Приазовье религиозных взаимоотношений между представителями разных религиозных групп в рамках концепции полимодельной системы межконфессиональных взаимоотношений.

Ключевые слова: религия, секта, православие, Приазовье, конфессиональные отношения, полимодельная система.

В XIX в. в Российской империи наблюдалась тенденция к резкому увеличению численности религиозных организаций сектантского толка и распространение новых религиозных учений, на что в значительной мере влияло возрождение местных духовных традиций и верований. Еще одним фактором роста стало дробление действующих религиозных организаций. Недостатки статистического учета религиозных организа-

(C) Санкт-Петербургский государственный университет, 2020

(C) Общецерковная аспирантура и докторантура им. святых равноапостольных Кирилла и Мефодия, 2020 
ций (в большинстве случаев представители новых религиозных обществ не желали их регистрировать официально) не позволяют в полной мере оценить степень распространение сектантов и раскольников на территории Российской империи. Трансформации в духовной сфере российского общества носили динамичный и нелинейный характер. По официальным данным Министерства внутренних дел Российской империи, в середине 1820-х годов в России было более 800 тыс. раскольников ${ }^{1}$, в 1862 г. этот показатель достиг еще более высокого уровня - «сектантов и раскольников в России несколько больше восьми миллионов» ${ }^{2}$. Такой разброс данных демонстрирует несовершенство системы подсчета и классификации. По результатам первой всеобщей переписи населения Российской империи 1897 г., численность сектантов оказалась свыше 176 тыс. ${ }^{3}$ Несмотря на увеличение численности сектантских объединений, есть аргументированные причины сомневаться в достоверности статистики в силу особенностей подсчета. Игумен Павел отмечает: «Министерские чиновники считали признаками раскола любые проявления “народного православия”, а также записывали в раскол всех, не ходивших на исповедь; то и другое вело к преувеличениям числа раскольников <...> количество которых в империи составляло 3 млн» 4

Цель настоящей статьи - изучение сектантских и раскольнических организаций, действовавших в Приазовье, на основе анализа архивных документов и законодательства Российской империи с привлечением исследований.

Новосозданные сектантские организации имели широкую социальную базу и динамично распространялись, несмотря на ограничения со стороны государства и требования к официальной регистрации, а также активную духовную деятельность Русской православной церкви по противодействию расширению сектантских организаций. Данные процессы проходили в большинстве регионов Российской империи, в том числе на территории Приазовья, и имели локальные особенности.

Приведенное выше мнение игумена Павла не совпадает с позицией Священного синода, который вплоть до начала XX в. не публиковал официальные сведения о численности и местах компактного проживания сектантов и раскольников.

Сектантские организации на территории Войска Донского, как и на других территориях Российской империи, существовали втайне, официально не афишируя свою религиозную принадлежность. Учение сектан-

${ }^{1}$ Приводится по: Варадинов Н.В. История Министерства внутренних дел. История распоряжений по расколу: в 8 кн. Кн. 8. СПб.: Типография Министерства внутренних дел, 1863. С. 179.

2 Эткинд А. Хлыст (секты, литература и революция). М.: Новое литературное обозрение, 1998. С. 12.

${ }^{3}$ Приводится по: Смолич И. К. История русской церкви: в 8 кн. Кн. 8, ч. 2. М.: Изд-во Спасо-Преображенского Валаамского монастыря, 1997. С. 170-172.

${ }^{4}$ Приводится по: Эткинд А. Хлыст. С. 35-36. 
тов распространялось подпольно, а в уставе многих мистических сект закреплялось неразглашение принадлежности к секте. Представители сектантства стремились минимизировать общение с представителями государственной власти, чтобы избежать государственного контроля и учета. Часть представителей сектантства маскировалась под православных и компактно проживала в границах того или иного церковного прихода, что делало задачу учета подобных групп крайне сложной. Так, скопцы и хлысты продолжали ходить в Русскую православную церковь, нередко являясь образцовыми прихожанами. Они не порывали с православием, в отличие от молокан, духоборов и субботников, которые считали, что ходить в церковь и поклоняться иконам не нужно. «Сектанты-мистики» посещали православные богослужения, но дополняли их собственной ритуальной практикой. Епархиальные архиереи практически не интересовались точными данными о таких сектантах, чтобы не получить на своей территории от Священного синода статус прихода с сектантскими организациями. И сами приходские священники, от которых поступали основные сведения, как правило, занижали численность сектантов, чтобы не показывать действительный уровень их распространения в приходе и не иметь замечаний со стороны Синода. Еще одной особенностью, которую приходилось учитывать в процессе учета численности сектантов, была их мобильность.

На численность сектантов влияли также некоторые особенности законодательства, которые несколько ограничивали миссионерскую деятельность Русской православной церкви, прежде всего относительно соблюдения государственных законов о духовных правах инородцев. В издании Свода законов 1832 г. данные правовые нормы были структурированы и собраны в единую систему. При этом возникла проблема практического применения данных законов, в первую очередь вследствие разницы между официальной терминологией и теми понятиями, которыми пользовались на практике. Так, понятие «инородец» в церковной, главным образом миссионерской, литературе, употребляли применительно ко всем неславянским народностям (включая, например, уже крещеных татар, чувашей, мордву Поволжья).

Юридические нормы о вере и культе инородцев были записаны в Уставах духовных дел иностранных исповеданий. Закон гарантировал свободу вероисповедания и отправления культа представителям нехристианских религий. Свод законов требовал от Русской православной церкви уважения свободы совести при обращении в православие и обязывал «поступать по правилам кротким, ограничиваясь одними убеждениями без малейших принуждений» ${ }^{5}$. Исследователь Н. М. Никольский полагал: «Предпосылки увеличения численности сект в России в XIX ст. связаны с социальными противоречиями - государственная церковь и старообрядческие орга-

${ }^{5}$ Приводится по: Боханов А. Российская империя. Образ и смысл. М.: ДиректМедиа, 2014. С. 441. 
низации в эпоху раннего капитализма были организациями господства и эксплуатации; секты были, напротив, за немногим исключением, такими организациями, которые создавались с первоначальной целью уйти от какого бы то ни было господства и только в процессе своего развития превращались также в организации господства. Секты создаются преимущественно в крестьянской среде, лишь иногда захватывая и городское мещанство» 6 .

При императоре Александре I государственная политика Российской империи была крайне веротерпимой, особенно по отношению к духоборам. В своем указе херсонскому губернатору от 1805 г Александр I четко зафиксировал границы применения законодательных актов по отношению к сектантам, которые нарушили закон. Также он издал указ «Общее правило, принятое мною на заблуждения сего рода...», в котором официально отказывался от государственного вмешательства в вопросы веры ${ }^{7}$.

После революционных событий император Николай I ужесточил государственную политику по отношению к носителям новых религиозных верований. П.В.Знаменский отмечал: «Царствование Николая I с начала до конца отличалось строго православным направлением и строгой цензурой, старавшейся предотвращать всякую открытую проповедь неправославных учений» ${ }^{8}$. На начало 1826 г. были запрещены молитвенные собрания скопцов, в обязанности центрального органа полиции, «III отделения Собственной Его Императорского Величества канцелярии», был включен сбор информации о действующих сектах 9 . В Свод законов 1832 г. ввели многочисленные статьи, направленные против сектантов, которые в Своде законов 1857 г. еще более расширились за счет включения указов, регламентировавших деятельность секретного комитета по надзору над сектами ${ }^{10}$.

Религиозная политика Александра II также ограничивала права сектантов и строго контролировала секты, что регламентировалось Сводом законов 1857 г. В 1858 г. архиепископ Никанор (Бровкович) охарактеризовал «Наставление для руководства при исполнительных действиях и сове-

${ }^{6}$ Никольский Н. М. Сектантство и развитие капитализма в России // Хрестоматия. Религия и общество. М.: Наука, 1996. С. 623. - См. также: Митрохин Л. Н. Баптизм: история и современность (философско-социологические очерки). СПб.: Изд-во Русского христианского гуманитарного института, 1997. С. 191.

${ }^{7}$ См. об этом: Поспеловский Д. Православная церковь в истории Руси, России, СССР. М.: Республика, 1996. С. 156.

${ }^{8}$ Приводится по: Оленич Т.С. Возникновение и трансформация русского сектантства / науч. ред. Е. Е. Несмеянов. Ростов н/Д. : Изд-во СКНЦ ВШ, 2004. С. 79.

${ }^{9}$ См. подробнее: Александров И. А. К вопросу о правовой политике российской империи в отношении секты скопцов во второй половине XIX - начале XX в. // Юридическая наука и правоохранительная практика. 2018. № 2 (44). С. 96.

${ }^{10}$ См. об этом: Апанасенок А. В. Старообрядческий мир Центрального Черноземья в XIX - начале XX в.: численность, расселение, социальный состав // Научные ведомости Белгородского государственного университета. Сер. История. Политология. Экономика. Информатика. 2009. № 9 (64), вып. 11. С. 141. 
щаниях по делам, до раскола относящимся» следующим образом: «...отказ от прежней вековой практики воздействия власти на всякие отпадения от господствующего вероисповедания» ${ }^{11}$. В 1881 г. обер-прокурор Священного синода К.П.Победоносцев представил императору материалы, свидетельствовавшие о связях сектантов с социалистами: «...ряд сектантов, отвергая все церковные обряды и таинства $<\ldots>$ не только не признают никаких властей и восстают против присяги и военной службы, уподобляя верных защитников престола и отечества разбойникам, но и проповедуют социалистические принципы, как, например, общее равенство, раздел имуществ и т. п.» ${ }^{12}$.

В переписке обер-прокурора с российскими дворянами читаем: «Теперь не время ограничивать как бы то ни было власть самодержавную, не время либеральничать. <..> Бог и совесть велят делать все, что нужно для защиты религии, царя, семьи его и семьи вообще» ${ }^{13}$.

На территории Екатеринославской губернии были те же сектантские организации, что и на других территориях Российской империи. Сектантство значительно распространилось в указанном регионе. По данным архивов, на 1825 г. в губернии официально учтено около 87 тыс. сектантов ${ }^{14}$. Однако эта цифра не представляет вполне точного количества сектантов на Дону. Появлялись новые группы, скрывающие свою принадлежность к сектантам. Наряду с ними функционировали немногочисленные организации, которые не входили в общины и, соответственно, не учтены в переписях. Так, молокане на территории Екатеринославской губернии не имели никакого единого центра, объединяющего их последователей. Каждая молоканская община была самостоятельной и руководствовалась лишь общим символом веры.

Согласно архивным материалам, молоканских сект в Приазовье было значительно больше, чем в целом по стране. Так, в соседних регионах, Владикавказе и Дагестане, функционировало всего лишь по одной организации молокан (918 и 55 приверженцев соответственно ${ }^{15}$ ), в Армавирском округе - 12 молоканских организаций с количеством прихожан свыше 2 тыс. чел. Наибольшее количество молоканских сект было в Таганрогском округе - 243 организации ${ }^{16}$.

На территориях, прилегающих к Дону, распространилась еще одна сектантская организация - хлысты. По данным архивов, наибольшее количество сект хлыстов насчитывалось в Кубанском округе - 9 общин, объединяющих 484 последователя, и в Терском округе -8 общин, объединяющих

${ }^{11}$ Приводится по: Тальберг Н. История христианской церкви. М.: Издательство Православного Свято-Тихоновского богословского ин-та, 2001. С. 57-58.

12 Приводится по: Оленич Т. С. Возникновение и трансформация... С. 23.

13 Приводится по: Там же. С. 24.

${ }^{14}$ Российский государственный исторический архив (далее - РГИА). Ф.842. Оп. 145. Д. 313. Л. 38.

15 Там же.

16 Там же. Ф. 455. Оп. 153. Д. 234. Л. 68. 
140 чел. ${ }^{17}$ По официальным данным, одна община хлыстов (130 чел.) действовала в Донецком округе; точное количество хлыстов в Донском и Таганрогском округах в официальных архивных документах не указано ${ }^{18}$.

Многочисленную группу сект Приазовья составляли евангелисты. Евангельских христиан насчитывалось на территории Донского края до 7 тыс. чел. Данное религиозное направление наиболее активно распространяло свое учение. Согласно архивным данным, евангельские секты были наиболее распространены в Кубанском, Майкопском, Терском и Армавирском округах: в Кубанском округе функционировало 29 общин, в Майкопском округе -8 , в Терском -16 , в Армавирском $-15^{19}$.

Также имелось достаточно большое количество сект адвентистов седьмого дня: на территории Донского округа - 25 общин; Армавирского - 27, Терского и Кубанского - 10 и 9 общин соответственно ${ }^{20}$. По структуре, быту и экономической базе эта секта похожа на общины евангельских христиан, в частности баптистов, однако «выше других стоит по интенсивности работы и строгому отбору членов» ${ }^{21}$. Она пользовалась наиболее значительной помощью из-за границы, откуда получала большое количество литературы ${ }^{22}$.

В Приазовье также широко распространился старообрядческий раскол. В Донской епархии единоверие ввели в 1840-х годах, а в 1841 г. открылся первый единоверческий старообрядческий храм. Согласно архивным материалам, большое количество старообрядческих общин функционировало на территории Сальского округа (область Войска Донского) - 20, они объединяли 4 тыс. приверженцев старообрядчества. Вторым по численности был Шахтинский округ -7 общин, объединявших около 13 тыс. чел. ${ }^{23}$

Согласно данным переписи населения 1873 г. в области Войска Донского, наибольшая часть старообрядцев проживала в станицах Первого Донского, Усть-Медведицкого и Второго Донского округов ${ }^{24}$.

Таким образом, «в 1879 г. в регионе насчитывалось староверов: приемлющих священство - 80301 чел., не приемлющих священства 18369 чел., не считая представителей иных направлений и сект (всего 99112 чел.). В 1882 г. число староверов уже насчитывало 104872 чел., из которых 103032 были из казачьего сословия» ${ }^{25}$.

17 Там же. Ф. 833. Оп. 132. Д. 313. Л. 67.

18 Там же. Ф. 824. Оп. 133. Д. 313. Л. 86.

19 Там же. Ф. 833. Оп. 132. Д. 313. Л. 67.

20 Там же. Ф. 824. Оп. 133. Д. 313. Л. 86.

${ }^{21}$ Никольский Н. М. Сектантство и развитие капитализма в России. С. 88.

22 Там же. С. 89.

${ }^{23}$ РГИА. Ф. 824. Оп. 133. Д. 313. Л. 86.

${ }^{24}$ Приводится по: Машковцев А.А., Машковиева В.В. Старообрядцы и сектанты Вятской губернии во второй половине XIX - начале XX в.: взаимоотношения с региональными властями православной церковью. Киров: Радуга-Пресс, 2015. С. 114-116.

${ }^{25}$ Ивановский Н.И. Руководство по истории и обличению старообрядческого раскола с присовокуплением сведений о сектах рационалистических и мистических: в 3 ч. Казань: Типография Императорского университета, 1889-1890. Ч. 3. С. 215. 
Как отмечает Н.И.Ивановский, «количество старообрядцев-беспоповцев точно определить невозможно из-за отсутствия духовенства и церковных служб, и, соответственно, не было никакого учета их количества ${ }^{26}$. По результатам переписи населения 1897 г., в области Войска Донского количество староверов составляло «около $5 \%$ населения, уступая только православному большинству» ${ }^{27}$.

Разнообразные секты Донского края можно разделить на группы по происхождению вероучения и организационной структуре. К первой группе относятся секты коренного российского происхождения: молокане, духоборы, хлысты, иеговисты и др., ко второй - секты «заграничного» происхождения: разнообразные евангельские христиане, баптисты, адвентисты седьмого дня и меннониты.

Секты, как и старообрядческие общины, включали в себя представителей различных общественных слоев. Деятельность разнообразных сект отражала важнейшие процессы в социальной жизни государства. Расширение сектантского движения среди крестьян в XIX в. было связано с постепенной ликвидацией крепостного права на территории всей Российской империи ${ }^{28}$. Православное священство объясняло рост численности сект и усиление их влияния отсутствием организованной миссионерской работы, «жизненной усталостью и скептицизмом» и влиянием Запада.

В процессах, которые происходили в Приазовье, влияние Русской православной церкви было очень значительным. Миссия церкви состояла в том, чтобы «приближаться к миру, обновлять его, вкладывая новое содержание в старый образ жизни, принимать местные национальные культуры и способы их выражения, не противоречащие христианской вере, преобразуя их в средства спасения» ${ }^{29}$.

Религиозные противоречия, которые могли возникнуть в ходе столкновения представителей разных религиозных верований, привели бы к достаточно масштабному конфликту, поэтому перед Департаментом духовных дел иностранных исповеданий стояла амбициозная задача: создать в регионе такую систему религиозных отношений, которая способствовала бы минимизации конфликтов на религиозной почве. Таким образом, в Приазовье фактически была создана оптимальная модель сосуществования компактно проживающих носителей разнообразных религиозных и культурных верований, или полимодельная система религиозных отношений, призванная служить гармонизации конфессиональных и национальных отношений и успешному маневрированию во имя избежания религиозных конфликтов. Тем не менее, несмотря на создание оптимальной

${ }^{26}$ Ивановский Н. И. Руководство по истории и обличению старообрядческого раскола... С. 216.

27 Апанасенок А. В. Старообрядческий мир Центрального Черноземья... С. 141.

${ }^{28}$ См. об этом: Брайбогль Н. Смена религии в православной империи. Политика религиозной принадлежности в России XIX в. // Tartaria Magna. 2012. № 1. С. 19.

${ }^{29}$ Концепция миссионерской деятельности Русской православной церкви // Pravmir. ru. URL: https://lib.pravmir.ru/library/readbook/2254 (дата обращения: 01.05.2020). 
на тот момент модели религиозных отношений, официальные представители царской власти сохраняли абсолютный контроль над процессами в религиозной сфере путем внедрения системы учета количества приходов, лиц обоих полов, исповедующих православие и носителей неправославного вероучения. На первый взгляд, такая система носила компромиссный характер, но, если проанализировать архивные материалы, православные приходы доминировали в вопросах регулирования религиозных отношений с сектантами. В чем тогда представляется компромисс? Рассмотрим более подробно полимодельную систему.

Во второй половине XIX в. в Приазовье формируется сложная религиозная структура, составляющая основу полимодельной системы религиозных отношений. В нее входят следующие элементы: «православные приходы, немецкие колонии (католики, лютеране) и еврейские колонии (иудаизм); греческие села (православие) и католики из меннонитских колоний, “старообрядческие” села (раскол) и села со смешанным населением (в регионе с доминирующими позициями православных конфессий создавались широкие возможности сосуществования и сотрудничества их с приверженцами лютеранства, иудаизма, католического вероисповедания, меннонитства и др.) ${ }^{30}$.

Основным структурным элементом полимодельной системы религиозных отношений стали православные приходы. «Краткий исторический очерк Екатеринославской губернии за 1912 г.» подтверждает наш вывод: «По вероисповеданиям православных и единоверцев - 90,05\%, католиков - 1,52\%, лютеран - 3,06\%, остальных христианских исповеданий $0,03 \%$, иудеев - 4,8\%, магометан - 0,1\%» ${ }^{31}$.

Подведем итоги. На территории Приазовья сложилась особая форма социально-духовных взаимоотношений - полимодельная система религиозных отношений, функционирование которой предполагало мирное сосуществование различных религиозных систем в регионе с единым структурным центром - православными приходами. Полимодельная система по своей сути была близка к компромиссной: духовная власть Российской империи относилась к сектантам терпимо. Однако религиозная деятельность сектантов пресекалась государством: за «совращение» православных прихожан в сектантскую веру полагалась каторга, за оскорбление православного священника - административное или уголовное наказание.

Точная информация о деятельности, численности и местах расселения религиозных организаций отсутствовала, что на фоне социально-политических процессов давало правительству Российской империи основание причислять носителей сектантских верований к враждебным государственному строю социальным объединениям. Именно это повли-

${ }^{30}$ Оленич Т. С. Возникновение и трансформация русского сектантства. С. 28.

31 Дынгес А. А. Римско-католическая церковь в Приазовье в начале XX в. // Летопись Донбасса: краеведческий сборник. Вып. 2. Донецк: Донбасс, 1994. С. 111. 
яло на создание системы жесткого контроля над количеством приходов и численностью верующих на тех территориях, где были распространены секты, в том числе на территории Приазовья. Однако меры государственного контроля над деятельностью религиозных организаций не имели системного характера, законодательные акты не были объединены в единую систему, что на фоне уклонения религиозных организаций от легализации дало возможность сектантским организациям продолжить свою деятельность в Приазовье и на всей территории государства.

Статья поступила в редакцию 25 мая 2020 г.

Статья рекомендована в печать 21 июля 2020 г.

Информация об авторе:

Оленич Тамара Станиславовна - д-р филос. наук, проф.; tamara1970@inbox.ru

Splits and sects in the Azov region and the authorities of the Russian Empire: Failed compromise in the nineteenth century

\section{T.S. Olenich}

Don State Technical University,

1, pl. Gagarina, Rostov-on-Don, 344000, Russian Federation

For citation: Olenich T. S. Splits and sects in the Azov region and the authorities of the Russian Empire: Failed compromise in the nineteenth century. Issues of Theology, 2020, vol. 2, no. 3, pp. 480-489. http://doi.org/10.21638/spbu28.2020.307 (In Russian)

The article discusses the features of the emergence and spread of sectarian organizations and Old Believer communities in the Azov region in the $19^{\text {th }}$ century. It is shown that the processes of the spread of sectarian organizations century were very active, which is explained by the fact that sectarian organizations had a broad social base and expanded dynamically, despite restrictions from the official government. The laws in force at that time limited the activities carried out by the Russian Orthodox Church in counteracting the process of promoting sectarian teachings at that time. The article illustrates that some of the representatives of sectarianism disguised themselves as Orthodox and compactly lived within the boundaries of church parishes. Proselytizing sectarianism was especially active in the territory of the Yekaterinoslav province by organizations such as the Molokans, Khlysts, Skoptsy, Old Believers, and others. This article characterizes the prevailing political and legal conditions for the spread of the sects, as well as the features of the system of religious relations that have developed in the region. On the basis of archival data, the number of such sects as the Molokans, the Whips, the Old Believers and the Evangelists, etc., was studied. The specificity of religious relations between representatives of different religious groups in the Azov region is analyzed within the framework of a unique phenomenon - a polymodel system of the interfaith relations.

Keywords: religion, sect, Orthodoxy, Azov region, confessional relations, polymodel system. 


\section{References}

Aleksandrov I. A. (2018) "On the issue of the legal policy of the Russian Empire in relation to the sect of the archers in the second half of the $19^{\text {th }}$ - early $20^{\text {th }}$ centuries", in Iuridicheskaia nauka i pravookhranitel'naia praktika, no. 2 (44), pp. 94-100. (In Russian)

Apanasenok A. V. (2009) “The Old Believers' World of the Central Black Earth Region in the $19^{\text {th }}-$ Early $20^{\text {th }}$ Centuries: Abundance, Resettlement, Social Composition", in Bulletin of Novgorod State University, Ser. History. Politology, no. 9 (64), iss. 11, pp. 140-147. (In Russian)

Bokhanov A.N. (2014) Russian Empire: image and meaning. Moscow, Direkt-Media Publ. (In Russian)

Brayfogl N. (2012) "Religion Change in the Orthodox Empire", in Tartaria Magna, no. 1, pp. $16-$ 47. (In Russian)

Dynges A.A. (1994) "Roman Catholic Church in the Azov region at the beginning of the $20^{\text {th }}$ century", in Letopis' Donbassa: kraevedcheskii sbornik, iss. 2, pp. 107-112. Donetsk, Donbass Publ.

Etkind A. (1998) Whip (sects, literature and revolution). Moscow, Novoe literaturnoe obozrenie Publ. (In Russian)

Ivanovskii N.I. (1889-1887) A guide to exposing the Old Believer schism, with the addition of information about rationalistic and mystical sects. In 3 vols, vol. 3. Kazan', Tipografiia Imperatorskogo Universiteta Publ. (In Russian)

Mashkovtsev A. A., Mashkovtseva V.V. (2015) Old Believers and sectarians of the Vyatka province in the second half of the $19^{\text {th }}$ - early $20^{\text {th }}$ centuries: relations with the regional authorities of the Orthodox Church. Kirov, Raduga-Press Publ. (In Russian)

Mitrokhin L. N. (1997) Baptism: history and modernity. St. Petersburg, Izd-vo Russkogo khristianskogo gumanitarnogo instituta Publ. (In Russian)

Nikol'skii N.M. (1996) "Sectarianism and the development of capitalism in Russia", in Khrestomatiia. Religiia i obshchestvo. Moscow, Nauka Publ. (In Russian)

Olenich T.S. (2004) The emergence and transformation of Russian sectarianism. Rostov on Don: Izd-vo SKNCz VSh Publ. (In Russian)

Pospelovskii D. (1996) Orthodox Church in the history of Rus', Russia, SSSR. Moscow, Respublika Publ. (In Russian)

Smolich I. K. (1997) History of the Russian Church. In 8 vols, vol. 8, part 2. Moscow, Izd-vo SpasoPreobrazhenskogo Valaamskogo monastyria Publ. (In Russian)

Tal'berg N. (2001) History of the Christian Church. Moscow, Saint Tikhon's theological institute Publ. (In Russian).

Varadinov N. V. (1863) History of the Ministry of the Interior. History of split orders. In 8 vols, vol. 8. St. Petersburg, Tipografia Ministerstva Vnutrennich Del Publ. (In Russian)

Received: May 25, 2020

Accepted: July 21, 2020

Author's information:

Tamara S. Olenich — Dr. Sci. in Philosophy, Professor; tamara1970@inbox.ru 